\title{
Developing Interactive Multimedia Based Learning Media for Foreign Students
}

\author{
Erma Febriani $^{1, *}$, Cahya Adi Prabowo ${ }^{2}$ \\ ${ }^{1}$ Department of Arabic Language Education, Faculty of Language Education, Universitas Muhammadiyah Yogyakarta \\ ${ }^{2}$ Department of Arabic Language Education, Faculty of Language Education, Universitas Muhammadiyah Yogyakarta \\ *erma.febriani@umy.ac.id
}

\begin{abstract}
The development of Interactive Multimedia is motivated by the unavailability of learning media to support the ability to find and analyze the contents of reading texts on the Qirotul Kutub material. Based on the problems that will be studied in this research, the objectives of this research are: To develop interactive multimedia material for Qirotul Kutub Arabic Language Education students. The type of research used in this research is R\&D (Research and Development) research. The results of the development of interactive multimedia on the technical quality aspect or display show that the technical or display quality aspect is in the "Very Feasible" criteria (90.75\%). The results of the field trial assessment of the quality aspects of learning materials in interactive multimedia stated that for the quality aspects of learning materials in the field trials the results were "Very Feasible" with an average of $91.14 \%$.
\end{abstract}

Keywords: Interactive Multimedia, Reading, Arabic

\section{INTRODUCTION}

Improving the quality of education is very important for the progress of higher education.Educational breakthroughs and innovations in the campus world are needed, especially in the development of learning models and media. The results of the development of technology-based learning models and media have been widely published in both online and offline scientific journals. Various scientific information is easily obtained by students who have access to this hightechnology. As a result, students who have access to high technology often feel dissatisfied with monotonous teaching.

The development of the times requires lecturers to make changes to the learning process so that students can more easily understand the material presented. One of the efforts made by thelecturer to improve student understanding in the learning process is the use of interactivemultimedia. There are many benefits of using interactive multimedia, namely: (1) students will bemotivated to learn because students do not feel bored; (2) students understand the material more easily because interactive multimedia is a combination of video, animation, graphics, and audio;

One of the materials in the Arabic Language Education Study Program is Qiroatul Kutub (Reading). The success of the teaching and learning process is determined by several components, from lecturers, students, learning objectives, materials (teaching materials), learning media, and the curriculum. Based on the observations of researchers in the Qiroatul Kutub class, the following were found: (1) the inadequate use of instructional media, especially interactive multimedia; (2) lecturers still have difficulty determining interactive media according to student needs. Therefore, researchers are interested in developing interactive multimedia as a supporting medium in teachingQiroatul Kutub. (3) the teaching and learning process can be carried out anywhere and anytime, so that it is not tiedonly to the classroom; (4) can improve student learning outcomes. Multimedia consists of two types, namely non-interactive and interactive multimedia. In non-interactive multimedia, users act passively and watch scene after scene sequentially. Meanwhile, interactive multimedia adds one more element, namely the interactive aspect so that users can actively select the desired scene and can also play simulations and games provided.

According to Hamalik in the book entitled "Learning Media" works Arsyad (2011) suggests that use of media in learning can arouse curiosity and new interests of students, increase motivation and stimulation in activities learn, and even influence psychology to students.

According to Robin and Linda (as quoted by Benardo, 2011) Interactive multimedia is a tool that can create dynamic and interactive presentations, which combines text, graphics, animation, audio and video images. The communication component in computer-based interactivemultimedia is the relationship between humans as users and computers in the form of applicationsoftware in a certain file format.

Based on the foregoing, this study seeks to develop interactive multimedia learning media to improve reading skills. Interactive multimedia from the results of this research will be a usefullearning medium for students. Students can improve their reading skills through materials that are 
presented attractively and can gain experience from doing the exercises that are given. So far, students prefer to be taught using multimedia rather than just listening to lecturers in lectures. Interactive multimedia has the potential to create a multisensory environment that supports certain learning styles. Sudhata \& Tegeh $(2015,23)$ state that multimedia has three functions, namely as an instructional aid, as an interactive tutorial and as a learning guide.

The results of research conducted by Hamidah Sidik (2018, 237-244) show that interactive learning media assisted by software Lectora inspires class X relations and functions developed with Brog and Gall Modified by Sugiyono is declared suitable for use by material experts and media experts with good criteria with an average assessment of material experts 4.2 and media experts 3.5. Participant response students towards interactive learning media assisted by Lectora software inspire the material relations and functions obtained good criteria with an average value of 4.0167 .

The results of research conducted by Aulia Mustika (2020, 17 -32) show that the Arabic learning problems can be overcome with the use of interactive multimedia.

\section{METHOD}

The type of research used in this research is research and development or R\&D (Researchand Development) research. Research and Development is research that is used to produce certain products, and to test the effectiveness of these products. To produce these products, beforehand, a needs analysis and testing of the effectiveness of the product must be carried out order to function properly in the wider community (Sugiyono, 2014: 407). The product developed in this research is interactive multimedia development for Foreign.

This Arabic interactive multimedia development procedure follows the steps of Lee \& Owens' development. This development procedure consists of five steps, namely: 1) analysis, 2) design, 3) development, 4) implementation, and 5) evaluation

\section{RESULT AND DISCUSSION}

The development of Interactive Multimedia is motivated by the unavailability of learning media to support the ability to find and analyze the contents of reading texts on the Qirotul $K u t u b$ material. Development of Interactive Multimedia to improve and develop students' abilities in finding and analyzing the contents of reading texts through speed reading.

The results of the initial interactive multimedia design are the result of a series of procedures, namely: needs analysis, planning, initial product format development, initial product validation, and initial product revision. Needs analysis was carried out by literature study, observation, interview and questionnaires to obtain information on the needs of learning media to be made. The activity begins with reading and observing the Qirotul Kutub book used by students and books on multimedia. After that, it was carried out with observations, questionnaires and interviews about the difficulties faced by students related to the Qirotul Kutub material and the use of learning media in the Qirotul Kutub class.

Planning is done through the formulation of specific objectives of the development of interactive multimedia models. The activity begins with making a checklist and list of problems to be solved from the results of interviews, observations, student questionnaires related to the Qirotul Kutub learning through discussions with the team. The following is a check list to formulate specific objectives according to the related field of science; a list of student problems and difficulties related to the Qirotul Kutub material, making the Qirotul Kutub teaching material, creating interactive multimedia. The list is used as a guide to determine specific objectives through study activities from the following related fields: looking at reference books for the Qirotul Kutub material which is a student guide book, collecting materials related to Qirotul Kutub material, looking at literature related to interactive multimedia-based teaching materials, looking at literature about making multimedia, finding goals, finding detailed information, finding conclusions, finding word references, finding vocabulary from information searches guided by the check list of needs above.

In the initial product validation stage, the researcher conducted a feasibility test by showing this interactive multimedia product to two experts, namely the Qirotul Kutub lecturer and an IT expert. The assessment is based on the ability of the media to meet specific objectives in the results of the planning phase. Before giving an assessment, the two experts were given explanation of the purpose of developing interactive multimedia.

The two experts above gave positive values in terms of learning materials and interactive multimedia display of Qirotul Kutub learning. In terms of material, this interactive multimedia has a clear purpose, where the material is presented in an attractive manner, equipped with pictures and mind mapping concepts, and clear instructions to make it easier for lecturers to convey the material and students in understanding it. In addition, the evaluation of learning is measurable and the results can be seen by students directly. Meanwhile, in terms of appearance, this application is designed with an appropriate background and a proportional layout. Then the letters / fonts are easy to read with the appropriate text color. In addition, the composition, size, and quality of the image display are good with animations that match the material. In terms of audio, the backsound is in accordance with the material, while in terms of packaging, the menu display is attractive and there is a match between the appearance and content. 


\subsection{Test Result Data}

Field trials were conducted on 3 students. Field trials produced data that would later measure the feasibility of the developed product, as well as to find out how the product benefits its users.

\subsubsection{Test Result Data for Phase II Individual Trial}

Table 1. Interactive Multimedia Assessment Score on Individual Trials About the Quality of Learning Materials

\begin{tabular}{|c|c|c|c|c|c|c|c|}
\hline \multirow{2}{*}{ No } & \multirow{2}{*}{ Rating Indicator } & \multicolumn{3}{|c|}{ Respondent } & \multirow{2}{*}{$\begin{array}{c}\text { Amount } \\
\text { Score }\end{array}$} & \multirow{2}{*}{$\begin{array}{l}\text { Average } \\
\text { percentage }\end{array}$} & \multirow{2}{*}{ Criteria } \\
\hline & & 1 & 2 & 3 & & & \\
\hline 1 & Material suitability & 4 & 4 & 4 & 12 & $80,00 \%$ & Feasible \\
\hline 2 & Clarity of study instructions & 4 & 4 & 5 & 13 & $86,67 \%$ & Very Feasible \\
\hline 3 & Ease of understanding sentences in the text & 4 & 4 & 5 & 13 & $86,67 \%$ & Very Feasible \\
\hline 4 & Easy to understand learning & 5 & 4 & 4 & 13 & $86,67 \%$ & Very Feasible \\
\hline 5 & Accuracy of serving order & 4 & 5 & 4 & 13 & $86,67 \%$ & Very Feasible \\
\hline 6 & Adequacy of practice & 4 & 4 & 4 & 12 & $80,00 \%$ & Feasible \\
\hline 7 & Feedback clarity & 4 & 5 & 4 & 13 & $86,67 \%$ & Very Feasible \\
\hline \multirow[t]{2}{*}{8} & Study assistance with the program & 4 & 4 & 4 & 12 & $80,00 \%$ & Feasible \\
\hline & Total Average & & & & & $84,17 \%$ & Very Feasible \\
\hline
\end{tabular}

The results of individual trials on the quality of learning materials in table 1 show that the material as a whole stated in the "very feasible" criteria.

Table 2. Interactive Multimedia Assessment Score On Individual Trials About Technical/Display Quality Aspects

\begin{tabular}{|c|c|c|c|c|c|c|c|}
\hline \multirow[t]{2}{*}{ No } & \multirow[t]{2}{*}{ Rating Indicator } & \multicolumn{3}{|c|}{ Respondent } & \multirow{2}{*}{$\begin{array}{c}\text { Amount } \\
\text { Score }\end{array}$} & \multirow{2}{*}{$\begin{array}{c}\text { Average } \\
\text { percentage }\end{array}$} & \multirow[t]{2}{*}{ Criteria } \\
\hline & & 1 & 2 & 3 & & & \\
\hline 1 & The beauty of the screen & 5 & 4 & 4 & 13 & $86,67 \%$ & Very Feasible \\
\hline 2 & Text legibility & 4 & 4 & 5 & 13 & $86,67 \%$ & Very Feasible \\
\hline 3 & Image and animation quality & 5 & 4 & 5 & 14 & $93,33 \%$ & Very Feasible \\
\hline 4 & Color composition & 5 & 4 & 5 & 14 & $93,33 \%$ & Very Feasible \\
\hline 5 & Navigation & 4 & 5 & 4 & 13 & $86,67 \%$ & Very Feasible \\
\hline 6 & Music support & 4 & 4 & 4 & 12 & $80,00 \%$ & Feasible \\
\hline 7 & Interaction & 4 & 4 & 4 & 8 & $80,00 \%$ & Feasible \\
\hline & Total Average & & & & & $82,86 \%$ & Very Feasible \\
\hline
\end{tabular}

Student responses to individual trials are shown in Table 2, it is explained that interactive multimedia from the aspect of technical quality or the majority display is rated as

"Very Feasible". Small group trials were conducted on 9 
students consisting of 3 students with high achievement, 3 students with moderate achievement, and 3 students with low achievement.
The assessment on the quality aspect of learning materials for small group trials described in table 3 shows that overall the criteria are "very feasible".

\subsubsection{Test Result Data For Phase III Small Group Trial}

Table 3. Interactive Multimedia Assessment Score Small Group Trial on the Quality Aspect of Learning Materials

\begin{tabular}{|c|c|c|c|c|c|c|c|c|}
\hline \multirow{2}{*}{ NO } & \multirow{2}{*}{ Rating Indicator } & \multicolumn{4}{|c|}{ Score } & \multirow{2}{*}{$\begin{array}{r}\text { Amount } \\
\text { Score }\end{array}$} & \multirow{2}{*}{$\begin{array}{l}\text { Average } \\
\text { percentage }\end{array}$} & \multirow{2}{*}{ Criteria } \\
\hline & & 1 & $\begin{array}{ll}2 & 3\end{array}$ & 4 & 5 & & & \\
\hline 1 & Material suitability & & & 3 & 6 & 42 & $93,33 \%$ & Very Feasible \\
\hline 2 & Clarity of study instructions & & & 4 & 5 & 41 & $91,11 \%$ & Very Feasible \\
\hline 3 & Ease of understanding sentence in the text & & & 2 & 7 & 43 & $95,56 \%$ & Very Feasible \\
\hline 4 & Easy to understand learning & & & 4 & 5 & 41 & $91,11 \%$ & Very Feasible \\
\hline 5 & Accuracy of serving order & & & 3 & 6 & 42 & $93,33 \%$ & Very Feasible \\
\hline 6 & Adecuacy of practice & & & 1 & 8 & 44 & $97,78 \%$ & Very Feasible \\
\hline 7 & Feedback clarity & & & 3 & 6 & 42 & $93,33 \%$ & Very Feasible \\
\hline 8 & Study assistance with the program & & & 4 & 5 & 41 & $91,11 \%$ & Very Feasible \\
\hline & Total Average & & & & & & $93,33 \%$ & Very Feasible \\
\hline
\end{tabular}

Table 4. Interactive Multimedia Assessment Score for Small Group Trials on Technical Quality Aspects or Appearance

\begin{tabular}{|c|c|c|c|c|c|c|c|c|c|}
\hline \multirow{2}{*}{ NO } & \multirow[b]{2}{*}{ Rating Indicator } & \multicolumn{5}{|c|}{ Score } & \multirow{2}{*}{$\begin{array}{c}\text { Amount } \\
\text { Score }\end{array}$} & \multirow{2}{*}{$\begin{array}{c}\text { Average } \\
\text { percentage }\end{array}$} & \multirow{2}{*}{ Criteria } \\
\hline & & 1 & 2 & 3 & 4 & 5 & & & \\
\hline 1 & The beauty of the screen & & & & 4 & 5 & 41 & $91,11 \%$ & Very Feasible \\
\hline 2 & Text legibility & & & & 4 & 5 & 41 & $91,11 \%$ & Very Feasible \\
\hline 3 & Image and animation quality & & & & 2 & 7 & 43 & $95,56 \%$ & Very Feasible \\
\hline 4 & Color composition & & & & 3 & 6 & 42 & $93,33 \%$ & Very Feasible \\
\hline 5 & Navigation & & & & 4 & 5 & 41 & $91,11 \%$ & Very Feasible \\
\hline 6 & Music support & & & 2 & 1 & 6 & 40 & $88,89 \%$ & Very Feasible \\
\hline 7 & Interaction & & & 3 & 1 & 5 & 38 & $84,44 \%$ & Very Feasible \\
\hline & otal Average & & & & & & & $90,79 \%$ & Very Feasible \\
\hline
\end{tabular}

The assessment on the technical quality aspect and appearance for the small group trial described in table 4 shows that overall it is in the "very feasible" criteria.

Based on the results of the student response questionnaire, the use of interactive multimedia reading as a medium in learning Arabic the material to find and analyze the main ideas of the reading text got a positive response (very feasible). However, speed reading Interactive multimedia should be slightly improved according to the suggestions contained in the response questionnaire. Interactive multimedia improvements for speed reading in the form of 
background color, type of writing, and writing size. Then after being repaired, interactive multimedia reading speed can be tested on a large scale

\subsubsection{Test Results Data for Phase IV Field Trials}

Field trials were conducted on 30 students. Field trials produce data that will later measure the feasibility of the product being developed, as well as to find out how the benefits of the product are for the user.

Table 5. Score of Interactive Multimedia Assessment Field Trials on the Quality Aspect of Learning Materials

\begin{tabular}{|c|c|c|c|c|c|c|c|c|}
\hline \multirow{2}{*}{ NO } & \multirow{2}{*}{ Rating Indicator } & \multicolumn{4}{|c|}{ Score } & \multirow{2}{*}{$\begin{array}{c}\text { Amount } \\
\text { Score }\end{array}$} & \multirow{2}{*}{$\begin{array}{l}\text { Average } \\
\text { percentage }\end{array}$} & \multirow{2}{*}{ Criteria } \\
\hline & & 1 & 23 & 4 & 5 & & & \\
\hline 1 & Material suitability & & & 14 & 16 & 136 & $90,67 \%$ & Very Feasible \\
\hline 2 & Clarity of study instructions & & & 15 & 15 & 135 & $90,00 \%$ & Very Feasible \\
\hline 3 & Ease of understanding sentence in the text & & & 17 & 13 & 133 & $88,67 \%$ & Very Feasible \\
\hline 4 & Easy to understand learning & & & 14 & 16 & 136 & $90,67 \%$ & Very Feasible \\
\hline 5 & Accuracy of serving order & & & 10 & 20 & 140 & $93,33 \%$ & Very Feasible \\
\hline 6 & Adecuacy of practice & & & 19 & 11 & 131 & $87,33 \%$ & Very Feasible \\
\hline 7 & Feedback clarity & & & 12 & 18 & 138 & $92,00 \%$ & Very Feasible \\
\hline 8 & Study assistance with the program & & & 10 & 20 & 140 & $93,33 \%$ & Very Feasible \\
\hline & Total Average & & & & & & $90,75 \%$ & Very Feasible \\
\hline
\end{tabular}

The results of the evaluation of interactive multimedia on the technical quality aspect or display show the results of student responses on the technical quality aspect or display for field trials and overall are in the "Very Feasible" criteria with a score of $90.75 \%$.

Table 6. Interactive Multimedia Assessment Score Field Trials on Technical Quality Aspects or Display

\begin{tabular}{|c|c|c|c|c|c|c|c|c|}
\hline \multirow[t]{2}{*}{$\mathrm{NO}$} & \multirow[t]{2}{*}{ Rating Indicator } & \multicolumn{4}{|c|}{ Scor } & \multirow{2}{*}{$\begin{array}{l}\text { Amount } \\
\text { Skcore }\end{array}$} & \multirow{2}{*}{$\begin{array}{l}\text { Average } \\
\text { percentage }\end{array}$} & \multirow[t]{2}{*}{ Criteria } \\
\hline & & 1 & 23 & 4 & 5 & & & \\
\hline 1 & The beauty of the screen & & & 14 & 16 & 136 & $90,67 \%$ & Very Feasible \\
\hline 2 & Text legibility & & & 10 & 20 & 140 & $93,33 \%$ & Very Feasible \\
\hline 3 & Image and animation quality & & & 13 & 17 & 137 & $91,33 \%$ & Very Feasible \\
\hline 4 & Color composition & & & 15 & 15 & 135 & $90,00 \%$ & Very Feasible \\
\hline 5 & Navigation & & & 16 & 14 & 134 & $89,33 \%$ & Very Feasible \\
\hline 6 & Music support & & & 12 & 18 & 138 & $92,00 \%$ & Very Feasible \\
\hline 7 & Interaction & & & 13 & 17 & 137 & $91,33 \%$ & Very Feasible \\
\hline & Total Average & & & & & & $91,14 \%$ & Very Feasible \\
\hline
\end{tabular}

The results of the field trial assessment of the quality aspects of learning materials in interactive multimedia stated that for the quality aspects of learning materials in the field trials the results were "Very Feasible" with an average of $91.14 \%$. 


\subsection{Discussion}

The teaching and learning process in the Qirotul Kutub course needs to utilize multimedia technology (interactive multimedia). Qirotul Kutub learning by using interactive multimedia can support the optimization of a fun learning process for students so that they are able to understand and master the material well. Interactive multimedia has an important role in the learning process and can make learning situations fun, creative and not boring. In the learning process, apart from teachers and students, two very important elements are learning methods and learning media (Hidayah, 2014:1).

So, multimedia is a tool that is able to convey messages in various ways, it can be in the form of text, graphics, images, sound, video and so on that support to improve the ability of the media to convey messages and make it easier for the recipient of the message to understand the message conveyed.

According to Khotimah (2016) interactive learning strategy is a learning method or technique used by teachers when presenting lesson materials, the teacher as the main actor in creating educational interactive situations, namely the interaction between teachers and students, students and students and with learning resources in supporting the achievement of learning objectives by using learning methods and media. Interactive learning is also an interactive learning process between teachers and students, students and students or between students and their environment. Through the process of interaction, it is possible for students' abilities to develop mentally and intellectually.

The interactive multimedia development product in the Qirotul Kutub course designed by the researcher is a material that has been developed by taking into account the learning and media aspects as the principles of learning message design. The product development research carried out resulted in a product in the form of interactive multimedia for the Qirotul Kutub material. The interactive multimedia produced in this study was made with interactive applications. This interactive multimedia presents material on how to find and analyze the main idea of a reading text through speed reading techniques. In addition, it is supported by Speed reading exercises. Multimedia display is made in color and balanced with text without disturbing students' concentration. It aims to make learning interesting and students do not get bored easily. Interactive multimedia speed reading supported by sound, video, and animation, aims to make students more motivated and enthusiastic so that learning objectives can be achieved

Based on the data from the validation results of material experts, learning design experts and software engineering experts, an assessment with very feasible criteria was obtained with several suggestions for improvement. Furthermore, the data on the results of trials conducted on students which included individual trials, small group trials and field trials obtained the results of the assessment with very feasible criteria. Overall, the results of the trial validation of the development of interactive learning media obtained a very decent assessment, which means that the interactive learning media on the Qirotul Kutub material is very suitable to be used to improve the quality of the learning process and student competence. Interactive learning media in the learning process is feasible to be used as an alternative to existing learning media.

This is supported by the previous findings of Ema Nuryani (2020) which states that the use of interactive learning media using macromedia flash is feasible to use where many media animations are inserted in the learning media so that it creates interest in students to learn.

Furthermore, the results of the study by Copriady (2014), concluded that the developed multimedia could improve student learning outcomes. Students who use interactive multimedia are 0.67 higher than learning using visual media with an increase of 0.41 , so it can be concluded that interactive multimedia has a significant influence on student learning outcomes. The use of interactive multimedia has a very big influence on improving student learning outcomes, this is because this multimedia is able to display materials. Able to display objects that do not actually exist physically or termed imagery.

Cognitively learning by using mental imagery will increase student retention in remembering subject matter (Munadi, 2008). This is because students directly interact and also interesting shows and animations can make students interested in learning the subject matter given. The use of interactive multimedia in the learning process can generate new desires and interests, generate motivation and stimulation of learning activities, and even have a psychological effect on students (Arsyad, 2013). Based on the results of the study, it can provide an illustration that the use of interactive multimedia can be used as a learning medium that can help improve student understanding for the better.

\section{CONCLUSION}

The development of Interactive Multimedia is motivated by the unavailability of learning media to support the ability to find and analyze the contents of reading texts on the Qirotul Kutub material. Interactive Multimedia Development is designed to improve and develop students' abilities in finding and analyzing the contents of reading texts through speed reading. In the process of developing interactive multimedia learning media there are several stages, namely: needs analysis, planning and developing the initial product format. In the needs analysis stage, literature study, observation, interviews and questionnaires were carried out to obtain information on the needs of the learning media to be made. At the planning stage, it is carried out through the formulation of specific objectives of developing interactive multimedia models. There are six steps in making, namely: targeting, topic selection, material maps, goal formulation, evaluation tools, and reference collection. At the development stage, the validity of the learning media and the validity of the content of the Qirotul Kutub material were carried out. 
From the results of the feasibility test of Interactive Multimedia, the expert assessment shows that interactive multimedia is very helpful for students in learning Qirotul $K u t u b$. Media experts also provide an evaluation of the advantages and disadvantages that must be improved in interactive multimedia. The results of the development show that the expert test and qualifying trials are very feasible by going through the product revision stage. The evaluation results of interactive multimedia on the technical quality aspect or display show the results of student responses on the technical quality aspect or display for field trials and overall the criteria are "Very Feasible" with a score of $90.75 \%$. While the results of the field trial assessment of the quality aspects of learning materials in interactive multimedia stated that for the quality aspects of learning materials in the field trials, the results were "Very Feasible" with an average of $91.14 \%$.

\section{ACKNOWLEDGMENTS}

Our gratitude goes to all those who have helped and played a role in research activities, especially to the funders of LP3M UMY. We also thank the research program partners, we hope that this collaboration can be well established and sustainable, so that it can work together to improve the Arabic language learning process well.

\section{REFERENCES}

[1] Arsyad,A.(2011).Media Pembelajaran. Jakarta: Rajagrafindo.

[2] A.Mustika.Multimedia Interaktif Untuk Mengatasi Problematika Pembelajaran Bahasa Arab. Al-Ta'rib. 8 (1).2020.17-32.

DOI: https://dx.doi.org/10.23971/altarib.v8i1.1902

[3] H. Sidik, Media Pembelajaran Interaktif Berbantu Software Lektora Inspire, Desimal. 1(2) (2018) 237 244. DOI: https://dx.doi.org/10.24042/djm.v1i2.2583

[4] Copriadi. Penggunaan Media Internet Elearning Berbasis Masalah Pada Materi Perubahan Lingkungan Untuk Meningkatkan Hasil Belajar Siswa. Scientiae Educatia.2014.DOI:https://dx.doi.org/10.24235/sc.educ atia.v6i2.1957

[5] Khaerotin R. Pengembangan Mulimedia Interaktif 3D Aurora Presentation Untuk Ketrampilan Menulis Arab. Al-Mahaara.2019.DOI: https://dx.doi.org/10.14421/almahara.2019.051-01

[6] Haki.M.L,AsrowiA.,Akhyar,A.Pengembangan Multimedia Interaktif Mata Pelajaran Bahasa Arab.JTPJurnal Teknologi Pendidikan.2018. DOI: https://dx.doi.org/10.21009/jtp.v20i3.9537 